\title{
TECHNOLOGY OF REDUCING CR(VI) ON LEATHER PROCESSING USING MIMOSA AS RETANNING AGENT
}

\section{Emiliana ANGGRIYANI ${ }^{1 *}$, Alfani Risman NUGROHO ${ }^{2}$, Nur Mutia ROSIATI ${ }^{1}$}

${ }^{1}$ Department of Leather Processing Technology, Politeknik ATK Yogyakarta, Sewon, Bantul, 55281, Yogyakarta, Indonesia, emiliana.anggry@gmail.com

${ }^{2}$ Department of Furniture Production Engineering, Politeknik Industri Furnitur dan Pengolahan Kayu, Kendal, Jawa Tengah Indonesia

https://doi.org/10.24264/Ifj.19.1.8

TECHNOLOGY OF REDUCING CR(VI) ON LEATHER PROCESSING USING MIMOSA AS RETANNING AGENT

ABSTRACT. Hexavalent chromium or $\mathrm{Cr}(\mathrm{VI})$ is toxic. Therefore, it is necessary to prevent or minimize its existence. This study aims to explain the effect of using mimosa as a retanning agent on the reduction of $\mathrm{Cr}(\mathrm{VI})$ content in goat crust skin. The post-tanning process was done by the process of $1^{\text {st }}$ retanning, neutralization, fatliquoring, $2^{\text {nd }}$ retanning and fixing. The retanning process 2 was performed with three treatments, $0 \%$ of mimosa, $3 \%$ of mimosa and $6 \%$ of mimosa. All the data were analyzed by the One Way ANOVA then followed by the Duncan Multiple Range Test. The results obtained were the decrease of hexavalent chromium content with the addition of mimosa during the retanning process. The use of $3 \%$ of mimosa is more effective to reduce the formation of $\mathrm{Cr}(\mathrm{VI})$ than $6 \%$ of mimosa. It can be said that the use of mimosa as a retanning agent can reduce the formation of $\mathrm{Cr}(\mathrm{VI})$.

KEY WORDS: $\mathrm{Cr}(\mathrm{VI})$, leather processing, mimosa, retanning agent

TEHNOLOGIE PENTRU REDUCEREA CONTIINUTULUI DE CR(VI) LA PRELUCRAREA PIEILOR UTILIZÂND MIMOSA CA AGENT DE RETĂBĂCIRE REZUMAT. Cromul hexavalent sau $\mathrm{Cr}(\mathrm{VI})$ este toxic. Prin urmare, este necesar să se prevină sau să se reducă la minimum existența acestuia. Acest studiu își propune să explice efectul utilizării agentului de retăbăcire mimosa asupra reducerii conținutului de $\mathrm{Cr}(\mathrm{VI})$ din pielea de capră nefinisată. Procesul de post-tăbăcire a fost realizat prin procesul de retăbăcire 1, neutralizare, ungere, retăbăcire 2 și fixare. Procesul de retăbăcire 2 a fost efectuat cu trei tratamente, $0 \%$ mimosa, 3\% mimosa și $6 \%$ mimosa. Toate datele au fost analizate utilizând metoda One Way ANOVA, efectuând apoi testul Duncan (metoda comparațiilor multiple). S-a obținut scăderea conținutului de crom hexavalent după adăugarea de mimosa în timpul procesului de retăbăcire. Utilizarea a 3\% mimosa este mai eficientă în reducerea formării de Cr(VI) decât 6\% mimosa. Se poate spune că utilizarea agentului de retăbăcire mimosa poate reduce formarea de $\mathrm{Cr}(\mathrm{VI})$.

CUVINTE CHEIE: Cr(VI), prelucrarea pieilor, mimosa, agent de retăbăcire

\section{TECHNOLOGIE DE REDUCTION DU TENEUR EN CR(VI) SUR LE TRAITEMENT DU CUIR EN UTILISANT MIMOSA COMME AGENT DE} RETANNAGE

RÉSUMÉ. Le chrome hexavalent ou $\mathrm{Cr}(\mathrm{VI})$ est toxique. Par conséquent, il est nécessaire d'empêcher ou de minimiser son existence. Cette étude vise à expliquer l'effet de l'utilisation du mimosa en tant qu'agent de retannage sur la réduction de la teneur en Cr(VI) de la peau de chèvre en croûte. Le processus de post-tannage a été effectué par le processus de retannage 1 , neutralisation, nourriture en bain, retannage 2 et fixation. Le processus de retannage 2 a été réalisé par trois traitements avec mimosa, $0 \%, 3 \%$ et $6 \%$. Toutes les données ont été analysées par One Way ANOVA puis par Duncan Multiple Range Test. On a obtenu la diminution de la teneur en chrome hexavalent avec l'ajout de mimosa au cours du processus de retannage. L'utilisation de $3 \%$ mimosa est plus efficace pour réduire la formation de $\mathrm{Cr}(\mathrm{VI})$ que $6 \%$ mimosa. On peut dire que l'utilisation de mimosa en tant qu'agent de retannage peut réduire la formation de $\mathrm{Cr}(\mathrm{VI})$.

MOTS CLÉS : $\mathrm{Cr}(\mathrm{VI})$, traitement du cuir, mimosa, agent de retannage

\footnotetext{
* Correspondence to: Emiliana ANGGRIYANI, Department of Leather Processing Technology, Politeknik ATK Yogyakarta, JI. Prof. Dr. Wirjono Projodikoro (Ringroad Selatan), Glugo, Panggungharjo, Sewon, Bantul, 55281, Yogyakarta, Indonesia, emiliana.anggry@gmail.com
} 


\section{INTRODUCTION}

Nowadays, the environment is in danger day by day. This is because of the hazardous chemicals that are used in the factories. One of the factories that might have a negative impact on the worse environment is the tannery industry. Tannery uses so many chemicals on leather processing. Waste treatment is needed to protect nature. One of the most dangerous forms is $\mathrm{Cr}(\mathrm{VI})$. $\mathrm{Cr}(\mathrm{VI})$ just appear on the wrong processing on leather making.

$\mathrm{Cr}$ (III) as a sulphate salt (green color), as a tanning agent, is entirely different in character from $\mathrm{Cr}(\mathrm{VI})$ on the orange color. $\mathrm{Cr}(\mathrm{VI})$ is highly toxic and as an oxidizer. $\mathrm{Cr}(\mathrm{VI})$ should not be used in the tanning industry. $\mathrm{Cr}(\mathrm{VI})$ is present in pigments/colors and the oxidation results of $\mathrm{Cr}$ (III) with oxidizing bleaching agents such as $\mathrm{H}_{2} \mathrm{O}_{2}, \mathrm{KMnO}_{4}$, fish oil and others [1].

Types of skin that require high density require the type of oil that can penetrate deeply into the skin. Fatliquoring agent with the type of fish oil or it is derivative or sulphited type (sulfonated oil) character has $\mathrm{SO}_{3}$ bound $\pm 6-7 \%$ [2]. Sulphited oil is more stable against changes in $\mathrm{pH}$ or minerals/salts so that sulphited oil will provide better penetration and lubrication than sulphated oil [3]. However the use of sulphited fish oil can trigger the formation of $\mathrm{Cr}(\mathrm{VI})$, therefore it is necessary to add tara or quebracho (1-3\%). The excessive use of those will affect the handle of leather [4].

$\mathrm{Cr}(\mathrm{VI})$ has a dangerous impact to the environment, that is why the chemical content $\mathrm{Cr}(\mathrm{VI})$ must not be used. It also has to be made sure that there is no chemical that change $\mathrm{Cr}(\mathrm{III})$ to $\mathrm{Cr}(\mathrm{VI})$. There are so many reasons why $\mathrm{Cr}(\mathrm{III})$ becomes $\mathrm{Cr}(\mathrm{VI})$, for example using fish oil, high temperature, oxidation of the process, etc. The conditions above must be avoided.

There is vegetable tanning agent that can avoid $\mathrm{Cr}(\mathrm{III})$ become $\mathrm{Cr}(\mathrm{VI})$. Tara is a vegetable tanning agent belonging to the pyrogallol tanning group. Tara is used in the chrome tanning process separately and in combination with myrobalan and protein hydrolysate. Tara is found to be inefficient when used individually in the chrome tanning process, however, when used in combination with myrobalan it plays a more effective role in controlling the oxidation of trivalent chromium to hexavalent chromium [5].
Because of the positive impact of using the vegetable retanning agent, there is a need to know about the effect of mimosa as one of the vegetable retanning agent on the reduction of the level of $\mathrm{Cr}(\mathrm{VI})$.

\section{EXPERIMENTAL}

\section{Materials and Methods}

\section{Instruments}

Drum process, knife, pH indicator, bucket, and scales.

\section{Materials}

Wet blue goat skins, $\mathrm{H}_{2} \mathrm{O}$, Surfactant, Formic Acid, Rokytan RHP, Sodium Format, Sodium-Naphthalene (Tanigan PAK), $\mathrm{NaHCO}_{3}$, Sulphited fish oil, Naphthalene sulfonate (Coralon OT), Mimosa, Preventol Cr.

\section{Post-Tanning Process}

A post-tanning process was started by washing the wet blue, then drain, $1^{\text {st }}$ retanning, washing, neutralization, drain, and rinse. Next process was fatliquoring, $2^{\text {nd }}$ retanning, fixing, drain and rinse. Treatment was done by making different treatments for using mimosa in the retanning process 2 . Treatment 1 without the use of mimosa ( $0 \%$ mimosa), Treatment 2 using $3 \%$ mimosa, and treatment 3 using $6 \%$ mimosa. Each done by 3 repetitions.

\section{Data Analysis}

Data were analyzed with IBM SPSS statistic 22. The analysis used was the One Way ANOVA then followed by the Duncan Multiple Range Test. Further results from crust skin were analyzed using FTIR (Fourier Transmitted Infra Red).

\section{RESULTS AND DISCUSSIONS}

\section{Chromium Cr(VI) Content}

Results in Table 1 showed that hexavalent chromium mean content in each treatment was significantly different $(P \leq 0.01)$. Hexavalent chromium means content of Treatment 1 was $8,9 \pm 0.13 \mathrm{mg} / \mathrm{kg}$, Treatment 2 was $4,58 \pm 0.02$ $\mathrm{mg} / \mathrm{kg}$ and Treatment 3 was $6,15 \pm 0.06 \mathrm{mg} / \mathrm{kg}$. It can be said that the addition of $3 \%$ of mimosa is 


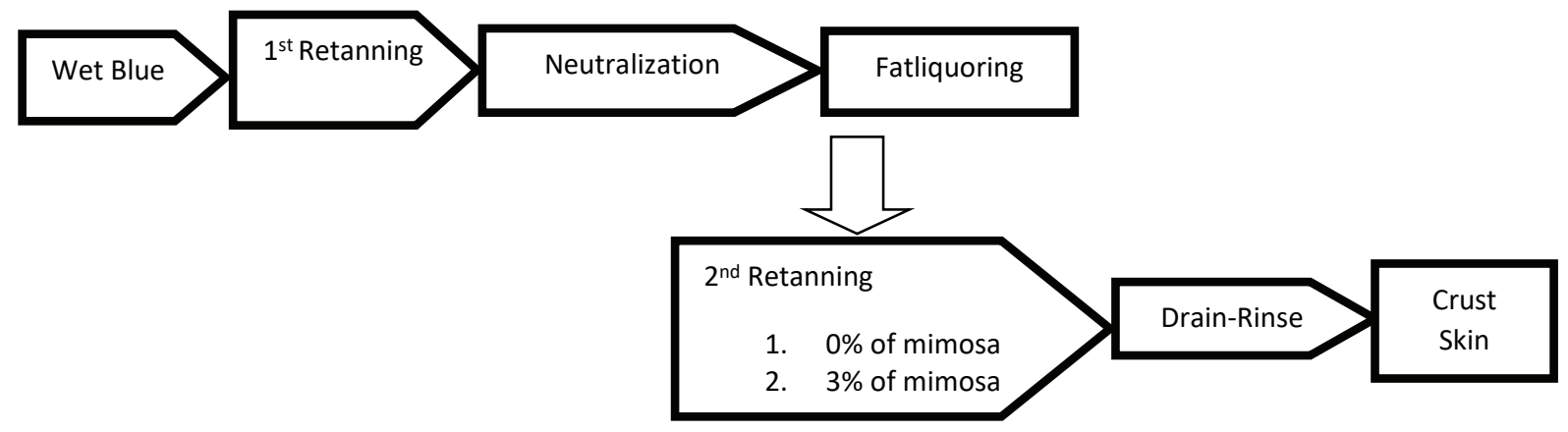

Figure 1. Diagrams of Post-Tanning Process

more effective to decrease $\mathrm{Cr}(\mathrm{VI})$ levels than the use of $6 \%$ of mimosa. The addition of retanning agent from vegetable can reduce the amount of $\mathrm{Cr}(\mathrm{VI})$ in the skin, better at lowering the level of $\mathrm{Cr}(\mathrm{VI})$ than without using mimosa. This was very important because the presence of $\mathrm{Cr}(\mathrm{VI})$ in the skin was an indication of the presence of toxins. Leather that will be used as goods used by humans must be free from toxic substances and allergic effects.

Table 1: Hexavalent Chromium Cr(VI) Mean Content (mg/kg)

\begin{tabular}{cccc}
\hline & Treatment 1 & Treatment 2 & Treatment 3 \\
\hline Wetblue & 14,57 & 14,57 & 14,57 \\
Crust & $8,9 \pm 0.13^{\mathrm{a}}$ & $4,58 \pm 0.02^{\mathrm{b}}$ & $6,15 \pm 0.06^{\mathrm{c}}$ \\
Percentage of reduction & $38.91 \%$ & $68.56 \%$ & $57.79 \%$ \\
\hline
\end{tabular}

$a, b, c$ : different superscript in the same line showed the highly significant difference $(P \leq 0.01)$

Percentage of reduction of $\mathrm{Cr}(\mathrm{VI})$ on Treatment 2 (3\% of mimosa) was $68.56 \%$. It was better than the other treatments. Suitable retanning process can afford lasting antioxidant protection. One percent of vegetable tanning agent (on wet blue weight), applied in the retanning process, is sufficient to meet the most demanding specifications. In order to ensure that the leather resists to an accelerated ageing process without forming $\mathrm{Cr}(\mathrm{VI})$, the protection conferred by this $1 \%$ will be sufficient for many skins/leather. But for other kinds of leather it will be necessary to increase the offer of vegetable extract to $2-3 \%$ depending on the fatliquoring agents, the thickness of the skin/hide, the dyeing process and the type of finishing [6].

Chestnut and mimosa tannins immobilized on chrome shaving matrices have been used directly as adsorbents for the recovery of $\mathrm{Cr}(\mathrm{VI})$ from polluted aqueous systems. Experimental studies indicated that immobilized tannin adsorbents can efficiently remove hexavalent chromium from water and raw shavings [7].
$\mathrm{Cr}(\mathrm{III})$ is assumed to be retained within the leather, whereas $\operatorname{Cr}(\mathrm{VI})$ is soluble $[8,9]$ that chromate $\mathrm{Cr}(\mathrm{VI})$ is considered to be a more potent allergen, and that $\mathrm{Cr}(\mathrm{VI})$ compounds are able to induce allergy and dermatitis at lower exposure levels than most $\mathrm{Cr}$ (III) compounds [10-12].

Mimosa can reduce $\mathrm{Cr}(\mathrm{VI})$ through adsorption mechanism. The mechanism by which metal ions are adsorbed onto different tannin resins has been a matter of considerable debate. Different studies have reached different conclusions. These include ion-exchange, surface adsorption, chemisorption, complexation, and adsorption-complexation. It is commonly believed that ion-exchange is the most prevalent mechanism. Metals react with phenolic groups of the tannin resins to release protons with their anion sites to displace an existing metal [13].

The addition of natural and bioproducts such as ascorbic acid, gallic acid, myrobalan, tara and protein hydrolysate in the pre tanning, tanning, wet finishing process carried out the chrome tanned leather on the formation of 
hexavalent chromium. The results imply that the $\mathrm{Cr}(\mathrm{VI})$ content of the wet blue leathers and crust leathers are below the detection limit. Myrobalan and tara can be used effectively in controlling the $\mathrm{Cr}(\mathrm{VI})$ in leathers. Tara is a vegetable tanning agent belonging to the pyrogallol tanning group. Tara is used in the chrome tanning process separately and in combination with myrobalan and protein hydrolysate. Tara is found to be inefficient when used individually in chrome tanning process, however when used in combination with myrobalan it plays more effective role in controlling the oxidation of trivalent chromium to hexavalent chromium [5].
Water resistant shoe upper leather in the form of crust or dyed leather did not contain $\mathrm{Cr}(\mathrm{VI})$ even after being subjected to extreme treatments. This leather was retanned with mimosa. In general vegetable retannage plays a significant role in avoiding chromate formation. Besides mimosa, quebracho, chestnut, and tara also showed a positive influence even when the leathers were exposed to extreme conditions like heat and UV radiation. Tara is particularly effective, on some leathers an offer below $1 \%$ was sufficient to suppress chromate formation [14].

\section{FTIR Analysis}

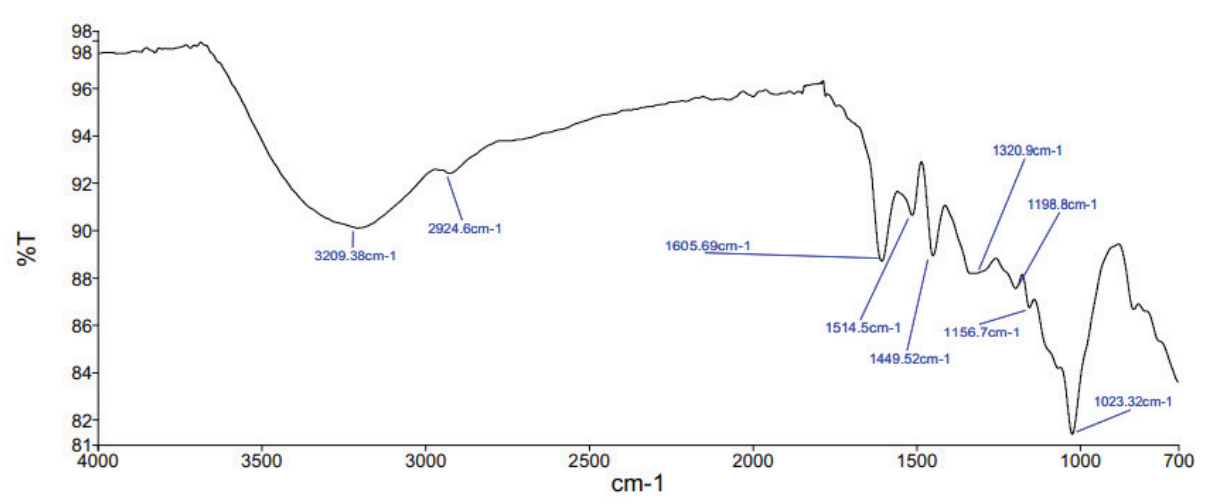

Figure 2. FTIR spectrum of mimosa

FTIR spectrophotometry was used to identify the functional groups contained in mimosa. The spectra is shown in Fig. 2. The strong band at $1023 \mathrm{~cm}^{-1}$ is characteristic of $\mathrm{C}-\mathrm{C}$, $\mathrm{C}-\mathrm{H}, \mathrm{C}-\mathrm{O}$ and aromatic ring vibrations [15]. The presence of aromatic rings was further confirmed by two bands of aromatic $\mathrm{C}-\mathrm{H}$ in-plane bending $\left(1157 \mathrm{~cm}^{-1}\right.$ and $\left.1199 \mathrm{~cm}^{-1}\right)[16,17]$ and a band of aromatic $\mathrm{C}=\mathrm{C}$ stretching $\left(1514 \mathrm{~cm}^{-1}\right)[18]$. $\mathrm{CH}$ bands were detected at $1321 \mathrm{~cm}^{-1}$ and 2925 $\mathrm{cm}^{-1}$ corresponding to $\mathrm{CH}$ deformation [19] and $\mathrm{CH}_{3} ; \mathrm{CH}_{2}$ stretching, respectively [20]. Kassim et al. (2011) argue that the broad and strong band observed at the region of $3200-3600 \mathrm{~cm}^{-1}$ attributes to $\mathrm{OH}$ stretching of hydrogen-bonded structures, while in this research it was found at $3209 \mathrm{~cm}^{-1}$ [21].

Fig. 3 shows the FTIR spectra of crust skins with various concentrations of mimosa used in the $2^{\text {nd }}$ retanning process. Functional groups of mimosa were detected in spectra of crust skins treated using mimosa concentrations of $3 \%$ and it of $6 \%$. A similarity of those spectra with the spectrum of crust skin treated $0 \%$ of mimosa is observed in this result. This is due to the similarity of functional groups containing in mimosa and in wet blue goatskin. Mimosa contains polyphenolic compounds [22] while wet blue goatskin contains collagen. Those two materials have hydroxyl $(\mathrm{OH})$ and methyl $\left(\mathrm{CH}_{3}\right)$ groups. Therefore, bands of these groups were found in spectra of untreated and treated wet blue skin with the mimosa.

The successful of $\mathrm{Cr}(\mathrm{VI})$ reduction using mimosa as retanning agent was proved by the presence of $\mathrm{C}=\mathrm{O}$ stretching vibration around $1735-1740 \mathrm{~cm}^{-1}$. This carbonyl $(\mathrm{C}=0)$ group is resulted from oxidation of hydroxyl group in 


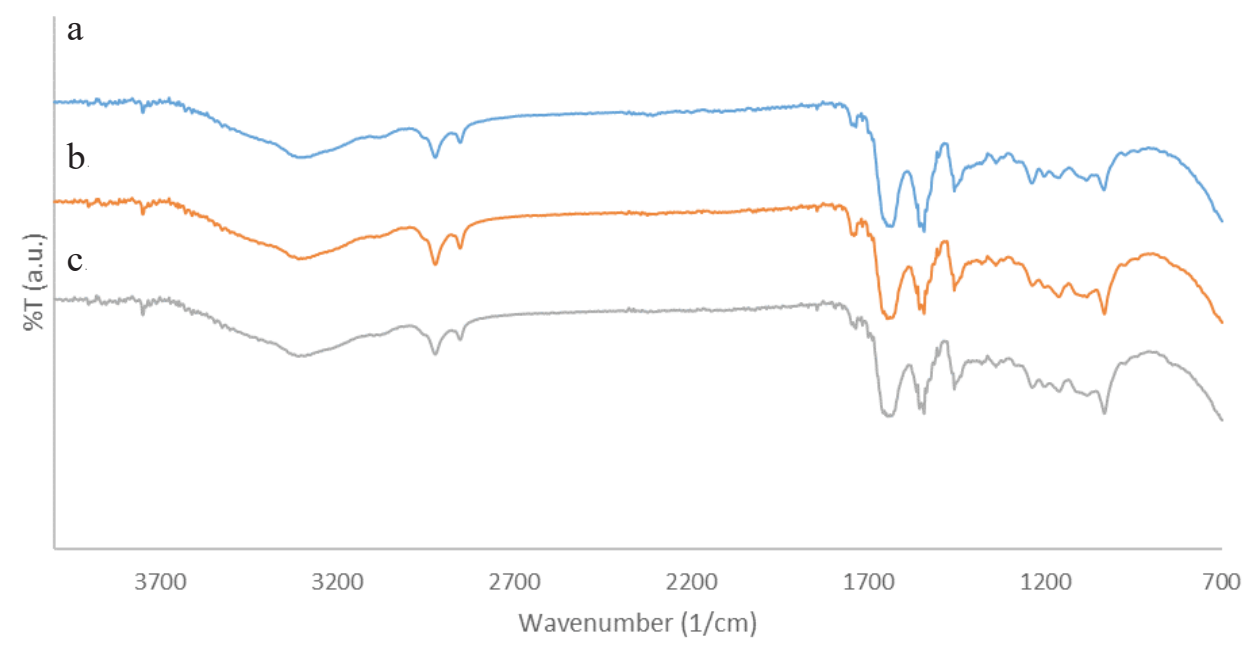

Figure 3. FTIR spectra of crust skins with various mimosa concentrations used in $2^{\text {nd }}$ retanning process (a) $0 \%$; (b) $3 \%$ and (c) $6 \%$

mimosa as a consequence of $\mathrm{Cr}(\mathrm{VI})$ reduction. Thus, this band is not detected in the mimosa FTIR spectrum. Furthermore, the forming of carbonyl groups leads the decrease of hydrogen bonds in mimosa. It is known from the alteration of $\mathrm{OH}$ band size around $3200-3600 \mathrm{~cm}^{-1}$, which is being narrow since the adding of mimosa. This explains that hydrogen bonds decrease for $\mathrm{C}-\mathrm{OH}$ oxidation forming $\mathrm{C}=\mathrm{O}$. Moreover the sharp bands at $2850-2930 \mathrm{~cm}^{-1}$ appeared in corresponding to the $\mathrm{CH}_{3}$ and $\mathrm{CH}_{2}$ stretching vibration. It is more clearly observed because $\mathrm{OH}$ broadband overlap does not occur in this spectra. This phenomenon also confirms the decrease in hydrogen bonding.

FTIR spectra shows the influence of mimosa concentration used in the $2^{\text {nd }}$ retanning process to functional groups contained in the material. Crust skin treated by $3 \%$ of mimosa (Treatment 2) has the sharpest $\mathrm{C}=\mathrm{O}$ band detected in this spectra. This shows that crust skin treated by $3 \%$ of mimosa has the most amount of $\mathrm{C}=\mathrm{O}$ describing the most amount of $\mathrm{Cr}(\mathrm{VI})$ reduced. Therefore, the optimum concentration of mimosa used as retanning agent is obtained at $3 \%$.

\section{CONCLUSIONS}

$\mathrm{Cr}(\mathrm{VI})$ is a very dangerous and toxic substance. However, in its development, not least the leather industry produces $\mathrm{Cr}(\mathrm{VI})$ in its leather products. Therefore, capable material was needed in reducing the formation of $\mathrm{Cr}(\mathrm{VI})$.
The addition of the vegetable retanning agent, in this case, mimosa can reduce the formation of $\mathrm{Cr}(\mathrm{VI})$. The optimum concentration of mimosa used as retanning agent to reduce the amount of $\mathrm{Cr}(\mathrm{VI})$ is obtained at $3 \%$.

\section{REFERENCES}

1. Purnomo, E., Greener Leather Processing, Politeknik ATK Yogyakarta, Yogyakarta, 2016.

2. Purnomo, E., Softy Leather, Akademi Teknologi Yogyakarta, 2011.

3. Purnomo, E., Pasca Tanning, Akademi Teknologi Kulit Yogyakarta, Yogyakarta, 2008.

4. Purnomo, E., Teknik Pasca Penyamakan Kulit Kecil, Polytechnic ATK Yogyakarta, 2017.

5. Devikavathi, G., Suresh, S., Rose, C., Muralidharan, C., Prevention of Carcinogenic $\mathrm{Cr}(\mathrm{VI})$ Formation in Leather-A Three Pronged Approach for Leather Products, Indian Journal of Chemical Technology, 2014, 7-13.

6. Font, J., Rius, A., Marsal, A., Sanchez, D., Hauber, C., Tommaselli, M., Prevention of Chromium(VI) Formation by Improving The Tannery Processes, IULTCS Congress, Istanbul, Turkey, May 2016, 1-7.

7. Chabaane, L., Tahiri, S., Albizane, A., El Krati, M., Cervera, M.L., De La Guardia, M., Immobilization of Vegetable Tannins on Tannery Chrome Shavings and Their Use for the Removal of Hexavalent Chromium form Contaminated Water, Chem Eng J, 2011, 310-317, https://doi.org/10.1016/j. cej.2011.09.037. 
8. Morris, G.E., 'Chrome' Dermatitis: A Study of The Chemistry of Shoe Leather With Particular Reference to Basic Chromic Sulfate, Arch Dermatol, 1958, 612-618, https://doi.org/10.1001/ archderm.1958.01560110058008.

9. Long, A., Cory, N., Wood, C., Potential Chemical Mechanisms Causing False Positive Results In Hexavalent Chromium Determination, I Soc Leath Technol Chem, 2000, 74-78.

10. Hedberg, Y.S., Liden, C., Odnevall Wallinder, I., Chromium Released From Leather - I: Exposure Conditions That Govern The Release of Chromium(III) and Chromium(VI), Contact Dermatitis, 2015, 72, 4, 206-15, https://doi. org/10.1111/cod.12329.

11.Hansen, M.B., Johansen, J.D., Menne, T., Chromium Allergy: Significance of Both $\mathrm{Cr}(\mathrm{III})$ and $\mathrm{Cr}(\mathrm{VI})$, Contact Dermatitis, 2003, 206-212, https://doi.org/10.1111/j.01051873.2003.0230.x.

12. Thyssen, J.P., Menne, T., Metal Allergy, A Review on Exposures, Penetration, Genetics, Prevalence, and Clinical Implications, Chem Res Toxicol, 2010, 309-318, https://doi. org/10.1021/tx9002726.

13.Mulani, K., Siona, D., Kishor, R., Sanjeev T., Nayaku, C., Tannin-Aniline-Formaldehyde Resole Resins for Arsenic Removal from Contaminated Water, Can Chem Trans, 2014, 2, 4, 450-466, https://doi.org/10.13179/ canchemtrans.2014.02.04.0123.

14. Hauber, C., Sources, Detection and Avoidance of Hexavalent Chromium in Leather and Leather Products, United Nations Industrial Development Organization, 1999.

15. Murugananthan, M., Bhaskar Raju, G., Prabhakar, S., Removal of tannins and polyhydroxy phenols by electro-chemical techniques, J Chem Technol Biotechnol, 2005, 80, 1188-1197, https://doi.org/10.1002/ jctb.1314.

16.Pardeshi, S., Dhodapkar, R., Kumar, A., Quantum chemical density functional theory studies on the molecular structure and vibrational spectra of Gallic acid imprinted polymers, Spectrochim Acta A, 2013, 116, 562-573, https://doi.org/10.1016/j. saa.2013.07.067.

17.Jensen, J.S., Egebo, M., Meyer, A.S., Identification of Spectral Regions for the
Quantification of Red Wine Tannins with Fourier Transform Mid-Infrared Spectroscopy, J Agr Food Chem, 2008, 56, 3493-3499, https://doi.org/10.1021/jf703573f.

18.Ahmad, L.O., Linh, L.H.M., Akimoto, M., Kaneki, Y., Honda, M., Suda, M., Kunimoto, K.K., Persimmon Tannin Gel: Formation by Autoxidation and Caffeine Adsorption Properties, Food Sci Technol Res, 2013, 19, 4, 697-703, https://doi.org/10.3136/ fstr.19.697.

19.Stewart, D., Fourier Transform Infrared Microspectroscopy of Plant Tissues, Appl Spectrosc, 1996, 50, 357-365, https://doi. org/10.1366/0003702963906384.

20.Ping, L., Pizzi, A., Guo, Z.D., Brosse, N., Condensed tannins from grape pomace: Characterization by FTIR and MALDI TOF and production of environment friendly wood adhesive, Ind Crop Prod, 2012, 40, 13-20, https://doi.org/10.1016/j. indcrop.2012.02.039.

21.Kassim, M.J., Hussin, M.H., Achmad, A., Dahon, M.H., Suan, T.K., Hamdan, H.S., Determination of total phenol, condensed tannin and flavonoid contents and antioxidant activity of Uncaria gambir extracts, Majalah Farmasi Indonesia, 2011, 22, 50-59.

22. Missio, A.L., Tischer, B., dos Santos, P.S.B., Codevilla, C., de Menezes, C.R., Barin, J.S., Haselein, C.R., Labidi, J., Gatto, D.A., Petutschnigg, A., Tondi, G., Analytical characterization of purified mimosa (Acacia mearnsii) industrial tannin extract: Single and sequential fractionation, Sep Purif Technol, 2017, 186, 218-225, https://doi. org/10.1016/j.seppur.2017.06.010.

(C) 2019 by the author(s). Published by INCDTP-ICPI, Bucharest, RO. This is an open access article distributed under the terms and conditions of the Creative Commons Attribution license (http://creativecommons.org/licenses/ by/4.0/). 